\section{p-ISSN 2476-9886 \\ e-ISSN 2477-0302 \\ J.Edu}

Volume 4 Nomor 1, April 2018, HIm 16-22

\section{Jurnal EDUCATIO}

Jurnal Pendidikan Indonesia

DOI: https://doi.org/10.29210/120182133

Akses Online :

http://jurnal.iicet.org

Dipublikasikan oleh :

Indonesian Institute for Counseling, Education and Therapy (IICET)

Info Artikel:

Diterima: 02/03/2018 Direvisi: 22/03/2018_Dipublikasikan: 15/04/2018

\title{
KONSEP SELF-ESTEEM SERTA IMPLIKASINYA PADA SISWA
}

\author{
Refnadi Refnadi ${ }^{1}$ \\ ${ }^{1}$ Indonesian Institute for Counseling, Education and Therapy (IICET)
}

\begin{abstract}
The process of achievement is an important part in the achievement itself. Achievement should be the result of honest hard work. In fact, to get the achievement, there are still many done with the road that is not good. One reason is the low self-esteem than students have. This text will describe the concept of selfesteem and the importance of students having a high self-esteem.
\end{abstract}

Keyword: self-esteem

(c) This is an open access article distributed under the Creative Commons Attribution License, which permits unrestricted use, distribution, and
reproduction in any medium, provided the original work is properly cited. (O)2017 by author and Indonesian Counselor Association (IKI).

\section{PENDAHULUAN}

Pembelajaran yang mendidik membangun hard skills dan soft skills sebagai suatu keutuhan. Pembelajaran yang mendidik, yakni proses mentransformasikan pengetahuan dan keterampilan yang sekaligus diiringi pengembangan karakter, kerja keras, kejujuran, dan peduli mutu, disertai evaluasi yang membangun objektivitas dan kejujuran. Proses belajar secara implisit merupakan ibadah (Dahlan, Refnadi, \& Zufriani, 2017), sehingga harus dilakukan dengan cara yang baik dan benar.

Hasil pemetaan akses dan mutu pendidikan tahun 2013 dan 2014 oleh The Learning Curve - Pearson dari 40 Negara menempatkan Indonesia posisi paling akhir, bahkan menurut UNESCO pada tahun 2012 minat baca orang Indonesia hanya $0,001 \%$, artinya hanya 1 dari 1.000 orang yang punya minat baca serius (Baswedan, 2014). Hal ini mengindikasikan bahwa pembelajaran di Indonesia masih belum optimal. Dalam upaya pencapaian hasil yang optimal, proses merupakan hal yang paling berperan penting. Namun pada kenyataannya, untuk memperoleh prestasi, masih banyak dilakukan dengan jalan yang tidak baik, misalnya dengan kasus perjokian, karena Nepotisme, dan mencontek (Besar \& Somad, 2012; Kartadinata, 2009; Pasaribu, 2011; Sujana \& Wulan, 1994). Tentu hal seperti ini akan mengurangi arti dari prestasi yang diraih, disamping kejujuran dalam meraih prestasi harus merupakan bagian dari prestasi itu sendiri (Kartadinata, 2009).

Dalam kegiatan belajar dapat timbul berbagai masalah baik bagi pelajar, misalnya pengaturan waktu belajar, memilih cara belajar, menggunakan buku-buku pelajaran, belajar berkelompok, motivasi belajar (Fitri, E., Ifdil, I., \& Neviyarni, S., 2016), mempersiapkan ujian, memilih mata pelajaran yang cocok, dan sebagainya (Yusuf \& Nurihsan, 2006). Permasalahan lain yang muncul pada remaja adalah kurang minatnya terhadap pendidikan, 
motivasi berprestasi rendah (Zola, N., Ilyas, A., \& Yusri, Y., 2017) bahkan membenci sekolah (Al-Mighwar, 2006). Pertama, remaja yang orangtuanya memiliki cita-cita tinggi yang tidak realistis terhadap prestasi akademik atau prestasi sosial yang terus mendesak untuk mencapai tujuan yang dikehendaki. Kedua, remaja yang kurang diterima oleh teman-teman sekelas, yang tidak mengalami kegembiraan teman-teman sekelas dalam berbagai kegiatan. Ketiga, remaja yang matang lebih awal fisiknya jauh lebih besar dibandingkan dengan teman-teman sekelasnya, karena penampilannya lebih tua dari usianya yang sesungguhnya, sering dia diharapkan berprestasi lebih baik melebihi kemampuannya. Ketiga jenis remaja yang kurang berminat pada pendidikan itu biasanya menunjukkan ciri-ciri ketidaksenangannya. Misalnya, berprestasi rendah, bekerja dibawah kemampuannya dalam setiap mata pelajaran atau dalam mata pelajaran yang tidak disukainya, membolos. Gejala seperti ini sering tampak pada yang mempunyai self-esteem rendah.

Untuk menghadapi permasalahan pendidikan, penting bagi siswa memiliki self-esteem yang tinggi. Dengan memiliki Self-esteem yang tinggi, dapat mencegah siswa untuk melakukan hal-hal negatif dalam meraih prestasi belajar. Self-esteem yang tinggi akan membuat seseorang merasa berharga, menghormati diri sendiri, memandang dirinya sejajar dengan orang lain dan selalu ingin maju dan berkembang. Sedangkan Self-esteem yang rendah membuat orang akan berhadapan dengan berbagai masalah sosial dan psikologis karena orang dengan harga diri rendah dianggap lebih rentan terhadap pengaruh negatif dari lingkungan sosial dan psikologis. Orang yang selfesteem Rendah juga akan mencari status dan pengakuan dalam kegiatan menyimpang (Owens, Stryker, \& Goodman, 2006).

\section{PEMBAHASAN}

Secara sederhana self-esteem dapat didefinisikan sebagai perasaan orang tentang diri mereka sendiri terkait dengan pentingnya prestasi, hubungan interpersonal yang positif, dan kesejahteraan psikologis (Vohs \& Baumeister, 2016). Self-esteem terbentuk melalui interaksi individu dengan lingkungan (Sandha, Hartati, \& Fauziah, 2012), jika hubungan memberikan sesuatu yang menyenangkan maka self-esteem menjadi positif, tapi jika lingkungan memberikan sesuatu yang tidak menyenangkan maka self-esteem akan menjadi negatif.

Self-esteem yang rendah telah terbukti berhubungan dengan banyak fenomena negatif, termasuk meningkatnya kehamilan remaja, penyalahgunaan narkoba, kekerasan, depresi, kecemasan sosial, dan bunuh diri. Faktor-faktor seperti jenis kelamin, ras, tingkat ekonomi, orientasi seksual, status imigran, dan lebih tampaknya dipengaruhi tingkat self-esteem (Guindon, 2009). Selain itu Dengan rendahnya self-esteem tentu hal ini akan menghambat siswa untuk berprestasi. Semakin tinggi self-esteem seseorang maka dapat membantu siswa tersebut untuk berprestasi dalam belajar, begitupun sebaliknya, semakin rendah self-esteem seseorang maka akan menghambat siswa untuk berprestasi (Adila, 2010; Irawati \& Hajat, 2012).

\section{Definisi Self-esteem}

Menurut Nathaniel Branden self-esteem adalah (1) keyakinan dalam kemampuan untuk bertindak dan menghadapi tantangan hidup ini. (2) keyakinan dalam hak kita untuk bahagia, perasaan berharga, layak, memungkinkan untuk menegaskan kebutuhan-kebutuhan dan keinginan-keinginan kita serta menikmati buah dari hasil kerja keras kita (Branden, 1992).

Self-esteem merupakan salah satu faktor keberhasilan individu dalam kehidupannya, karena perkembangan self-esteem pada seorang remaja akan menentukan keberhasilan maupun kegagalan dimasa mendatang. Sebagai penilaian terhadap diri sendiri, maka pengembangan self-esteem menjadi bagian penting dalam pendidikan karena diharapkan mampu memproses penemuan konsep diri positif pada jiwa anak.

Self-esteem adalah evaluasi individu untuk mengubah atau untuk mengembangkan keterampilan sosial, fisik dan akademis (Lawrence, 2006). Untuk anak usia sekolah self-esteem terus terpengaruh terutama oleh orangorang penting dalam kehidupan mereka. Proses perkembangan self-esteem dimulai dengan hubungan interpersonal dalam keluarga yang secara bertahap terpengaruh dari sekolah dan pengaruh dari masyarakat yang lebih luas di mana individu memilih untuk tinggal dan bekerja yang berakhir pada potensi mereka untuk sejauh mana individu menjadi penentuan nasib sendiri (Nikmarijal, 2014). 
Senada dengan itu Rusli Lutan memaparkan bahwa self-esteem adalah penerimaan diri sendiri, oleh diri sendiri berkaitan bahwa kita pantas, berharga, mampu dan berguna tak peduli dengan apa pun yang sudah, sedang atau bakal terjadi. Tumbuhnya perasaan aku bisa dan aku berharga merupakan inti dari pengertian self-esteem (Lutan, 2003).

Menurut Maslow, harga diri sebagai suatu kebutuhan yang harus dipenuhi oleh manusia (Rohmah, 2012). Kebutuhan akan rasa harga diri ini oleh Maslow dibagi menjadi dua bagian yaitu : (1) Penghormatan atau penghargaan dari diri sendiri yang mencakup hasrat untuk memperoleh kompetensi, rasa percaya diri, kekuatan pribadi, adekuasi, kemandirian dan kebebasan. Individu ingin mengetahui atau yakin bahwa dirinya berharga serta mampu mengatasi segala tantangan dalan hidupnya. (2) Penghargaan dari orang lain, antara lain prestasi. Dalam hal ini individu butuh penghargaan atas apa-apa yang dilakukannya (Sri Mendari, 2013).

Self-esteem mempengaruhi motivasi, perilaku fungsional, dan kepuasan hidup, dan terkait secara signifikan untuk kesejahteraan sepanjang hidup. Ada kemungkinan bahwa perilaku dimaksudkan untuk mempertahankan dan meningkatkan rasa positif dari diri yang universal, bahwa harga diri adalah kebutuhan dasar manusia (Guindon, 2009).

Jadi dapat disimpulkan bahwa self-esteem adalah; (1) penilaian seseorang secara umum terhadap dirinya sendiri, baik berupa penilaian negatif maupun penilaian positif yang akhirnya menghasilkan perasaan keberhargaan atau kebergunaan diri dalam menjalani kehidupan. (2) kemampuan untuk memahami apa yang dapat dilakukan dan apa yang telah dilakukan, (3) penetapan tujuan dan arah hidup sendiri, (4) kemampuan untuk percaya pada kemampuan sendiri, dan tidak merasa iri terhadap prestasi orang lain.

\section{Komponen Self-esteem}

Menurut Battle (Marjohan, 1997), komponen self-esteem terdiri atas tiga, yaitu: a.general self-esteem, b.social self-esteem, c.personal self-esteem.

\section{General Self-esteem}

General self-esteem mengacu pada perasaan keseluruhan seseorang terhadap self-worth yang bertentangan dengan self-esteem dalam kaitannya dengan aktivitas tertentu atau keterampilan dan perasaan harga diri dan kepercayaan diri serta persepsi keseluruhan individu dari nilai mereka yang merupakan hasil dari pengalaman masa lalu dan sejarah individu.

Self-esteem juga digunakan sebagai variabel independen, yaitu sebagai penyebab dari perilaku. Seorang individu dikatakan berperilaku dengan cara tertentu karena tinggi atau rendahnya tingkat self-esteem. Beberapa berpendapat bahwa pemeliharaan self-esteem, seseorang adalah kebutuhan dasar. Kebutuhan untuk terlihat baik, baik secara pribadi maupun publik begitu menyebar sehingga individu akan berperilaku dengan cara yang mempertahankan harga diri mereka. Semua aspek self-esteem saling terkait. General self-esteem mempengaruhi tujuan dan kegiatan yang sedang dalam proses, dan juga membantu menentukan perilaku sehari-hari.

Social Self-esteem

Social self-estem adalah aspek harga diri yang mengacu pada persepsi individu terhadap kualitas hubungan mereka dengan teman sebaya serta kemampuan untuk terlibat dalam interaksi interpersonal individu hidup dalam dunia sosial. Kenyamanan merupakan hal yang penting untuk interaksi sosial.

Dalam studi terakhir social self-esteem secara luas diperkirakan penanda penting dari kesehatan psikososial, seperti ukuran jaringan dukungan interpersonal dan sosial, penyesuaian pribadi dan psikopatologi.

\section{Personal Self-esteem}

Personal self-esteem adalah cara melihat diri sendiri dan berkaitan erat dengan self-image. Hal ini sangat penting karena akan mempengaruhi cara seseorang merasa tentang dirinya dan bagaimana seseorang berperilaku dalam situasi yang menantang.

Yang paling penting untuk disadari tentang personal self-esteem adalah bahwa hal itu berhubungan dengan bagaimana orang lain melihat Anda. Dalam hal ini seseorang akan berada pada harmoni dengan dunia dan orang 
lain di sekitarnya atau dapat sangat berbeda dari bagaimana orang lain melihat dirinya dan sebagainya. Individu mungkin merasa salah paham dan merasa hidup adalah pertempuran untuk membuat orang lain menghargai siapa dirinya.

Salah satu masalah terbesar orang dengan personal self-esteem adalah mereka tidak dapat menerima atau mungkin buta terhadap siapa mereka dan apa yang mereka yakini. Sebagian besar dari kita hari ini menderita sampai batas tertentu karena masyarakat tampaknya ingin kita untuk bersikap dan hidup dengan cara yang mungkin tidak persis dengan apa yang kita inginkan.

Langkah pertama menuju self-esteem yang lebih tinggi adalah menjadi jelas tentang siapa dan apa yang percaya. Ini adalah tujuan dari kesadaran diri. Sebelum individu dapat meningkatkan self-esteem atau bahkan membuat perubahan positif bagi hidup dirinya, seseorang perlu menyediakan waktu untuk membentuk perbaikan diri. Oleh karena itu, memahami personal self-esteem adalah langkah pertama yang diperlukan dan hanya setelah langkah ini seseorang dapat berpikir tentang bagaimana mengubah hidup secara positif.

\section{Karakteristik Self-esteem}

Self-esteem seseorang tergantung bagaimana dia menilai tentang dirinya yang dimana hal ini akan mempengaruhi perilaku dalam kehidupan sehari-hari. Penilaian individu ini diungkapkan dalam sikap-sikap yang dapat bersifat tinggi dan negatif.

\section{Karakteristik Harga Diri Tinggi}

Harga diri yang tinggi akan membangkitkan rasa percaya diri, penghargaan diri, rasa yakin akan kemampuan diri, rasa berguna serta rasa bahwa kehadirannya diperlukan didalam dunia ini. Contoh : seorang remaja yang memiliki harga diri yang cukup tinggi, dia akan yakin dapat mencapai prestasi yang dia dan orang lain harapkan. Pada gilirannya, keyakinan itu akan memotivasi remaja tersebut untuk sungguh-sungguh mencapai apa yang diinginkan.

Berdasarkan survei yang dilakukan Mary H Guindon, peserta diminta untuk membuat daftar lima karakteristik masing-masing yang paling menggambarkan siswa dengan self-esteem yang tinggi dan siswa selfesteem yang rendah didapatkan gambaran seperti terlihat pada gambar. 


\begin{tabular}{|c|c|c|c|}
\hline High Self-Esteem & $n$ & Low Self-Esteem & $n$ \\
\hline 1. Confident & 267 & 1. Withdrawn/shy/quiet & 140 \\
\hline 2. Friendly/outgoing & 189 & 2. Insecure & 138 \\
\hline 3. Happy & 153 & 3. Underachieving & 131 \\
\hline 4. Positive/optimistic & 118 & 4. Negative (attitude) & 120 \\
\hline 5. Motivated & 98 & 5. Unhappy & 110 \\
\hline 6. Achieving & 89 & 6. Socially inept & 101 \\
\hline 7. Competitive/risk taker & 88 & 7. Angry/hostile & 91 \\
\hline 8. Accepting/tolerant & 85 & 8. Unmotivated & 84 \\
\hline 9. Involved/active & 78 & 9. Depressed & 83 \\
\hline 10. Secure/well adjusted & 75 & 10. Dependent/follower & 82 \\
\hline 11. Comfortable w/ self & 74 & 11. Poor self-image & 75 \\
\hline 12. Assertive & 59 & 12. Non-risk taker & 66 \\
\hline 13. Caring & 53 & 13. Lacks self-confidence & 62 \\
\hline 14. Independent & 52 & 14. Poor communicator & 47 \\
\hline 15. Responsible & 50 & 15. Acts out & 39 \\
\hline Other & 432 & Other & 578 \\
\hline \multicolumn{4}{|c|}{$\begin{array}{l}\text { Note: } 412 \text { of } 418 \text { respondents answered this question. } \\
n=\text { number of responses. } \\
\text { a } 27 \text { additional terms. } \\
\text { b } 34 \text { additional terms. }\end{array}$} \\
\hline
\end{tabular}

Gambar 1. Hasil survey Mary H Guindon (2009) tentang karakteristik self- esteem siswa

Manfaat dari dimilkinya harga diri yang tinggi, diantaranya :

(1) Individu akan semakin kuat dalam menghadapi penderitaan-penderitaan hidup, semakin tabah, dan semakin tahan dalam menghadapi tekanan-tekanan kehidupan, serta tidak mudah menyerah dan putus asa.

(2) Individu semakin kreatif dalam bekerja

(3) Individu semakin ambisius, tidak hanya dalam karier dan urusan finansial, tetapi dalam hal-hal yang ditemui dalam kehidupan baik secara emisional, kreatif maupun spiritual.

(4) Individu akan memilki harapan yang besar dalam membangun hubungan yang baik dan konstruktif.

(5) Individu akan semakin hormat dan bijak dalam memperlakukan orang lain, karena tidak memandang orang lain sebagai ancaman (Branden, 1992).

a) Karakteristik Harga Diri Rendah

Remaja yang memiliki harga diri rendah akan cenderung merasa bahwa dirinya tidak mampu dan tidak berharga (Rohmah, 2012). Remaja dengan harga diri rendah cenderung untuk tidak berani mencari tantangantantangan baru dalam hidupnya, lebih senang menghadapi hal-hal yang sudah dikenal dengan baik serta menyenangi hal-hal yang tidak penuh dengan tuntutan, cenderung tidak merasa yakin akan pemikiran-pemikiran serta perasaan yang dimilikinya, cenderung takut menghadapai respon dari orang lain, tidak mampu membina komunikasi yang baik dan cenderung merasa hidupnya tidak bahagia (Engko, 2006; Kurniasari, 2015; Nirmalasari \& Masusan, 2014).

\section{Pembentukan Self-esteem}

Harga diri mulai terbentuk setelah anak lahir, ketika anak berhadapan dengan dunia luar dan berinteraksi dengan orang-orang di lingkungan sekitarnya. Interaksi secara minimal memerlukan pengakuan, penerimaan peran yang saling tergantung pada orang yang bicara dan orang yang diajak bicara. Interaksi menimbulkan pengertian tentang kesadaran diri, identitas, dan pemahaman tentang diri. Hal ini akan membentuk penilaian 
individu terhadap dirinya sebagai orang yang berarti, berharga, dan menerima keadaan diri apa adanya sehingga individu mempunyai perasaan harga diri (Burns, 1993).

Harga diri mengandung pengertian "siapa dan apa diri saya". Segala sesuatu yang berhubungan dengan seseorang, selalu mendapat penilaian berdasarkan kriteria dan standar tertentu, atribut-atribut yang melekat dalam diri individu akan mendapat masukan dari orang lain dalam proses berinteraksi dimana proses ini dapat menguji individu, yang memperlihatkan standar dan nilai diri yang terinternalisasi dari masyarakat dan orang lain.

\section{SIMPULAN DAN SARAN}

Prestasi dalam pendidikan haruslah diperoleh dengan jalan yang baik, proses merupakan bagian yang penting. Self-esteem menjadi salah satu faktor yang berpengaruh terhadap masing-masing diri siswa yang berimplikasi terhadap proses pembelajaran di sekolah. Dengan memiliki Self-esteem yang tinggi, dapat mencegah siswa untuk melakukan hal-hal negatif dalam meraih prestasi belajar. Untuk kedepan perlu penelitian lebih lanjut untuk melihat hubungan dan pengaruh self-esteem terhadap prestasi belajar, serta upaya yang bisa dilakukan untuk meningkatkan self-esteem yang dimilik siswa.

\section{DAFTAR RUJUKAN}

Adila, M. D. (2010). Hubungan self esteem dengan optimisme meraih kesuksesan karir pada mahasiswa fakultas Psikologi UIN Syarif Hidayatullah Jakarta.

Al-Mighwar, M. (2006). Psikologi remaja petunjuk bagi guru dan orang tua. Bandung: Pustaka Setia.

Baswedan, A. R. (2014). Gawat darurat pendidikan di Indonesia. Paper presented at the The Emergency of Indonesian Education]. A paper delivered at the meeting between Ministry and Head of Education Offices Indonesia-wide in Jakarta, on December.

Besar, P. P. G., \& Somad, H. A. (2012). PENDIDIKAN KEIMANAN UNTUK MENCAPAI MANUSIASEUTUHNYA.

Branden, N. (1992). The power of self-esteem. Florida: Health Communications: Inc.

Burns, R. (1993). Konsep Diri: Teori, pengukuran, perkembangan dan perilaku. Jakarta: Arcan.

Dahlan, D., Refnadi, R., \& Zufriani, Z. (2017). Pengintegrasian Motif Ibadah Pendidik Sebagai Upaya Optimalisasi Pencapaian Tujuan Pendidikan. Jurnal Konseling dan Pendidikan, 5(3), 115-122.

Engko, C. (2006). Pengaruh kepuasan kerja terhadap kinerja individual dengan self esteem dan self efficacy sebagai variabel intervening. Simposium Nasional Akuntansi, 9, 23-26.

Fitri, E., Ifdil, I., \& Neviyarni, S. (2016). Efektivitas layanan informasi dengan menggunakan metode blended learning untuk meningkatkan motivasi belajar. Jurnal Psikologi Pendidikan dan Konseling: Jurnal Kajian Psikologi Pendidikan dan Bimbingan Konseling, 2(2), 84-92.

Guindon, M. H. (2009). Self-esteem across the lifespan: Issues and interventions: Taylor \& Francis.

Irawati, N., \& Hajat, N. (2012). Hubungan antara harga diri (self esteem) dengan prestasi belajar pada siswa SMKN 48 di Jakarta Timur. Econosains Jurnal Online Ekonomi dan Pendidikan, 10(2), 193-210.

Kartadinata, S. (2009). Terapi dan Pemulihan Pendidikan. Bandung: Universitas Pendidikan Indonesia.

Kurniasari, A. (2015). Kekerasan Versus Disiplin dalam Pengasuhan Anak. Sosio Informa.

Lawrence, D. (2006). Enhancing self-esteem in the classroom: Pine Forge Press.

Lutan, R. (2003). Self Esteem: Landasan Kepribadian. Jakarta: Bagian Proyek Peningkatan Mutu Organisasi dan Tenaga Keolahragaan Dirjen Olahraga Depdiknas.

Marjohan. (1997). An investigation of factors that influence decision making and their relationship to self-esteem and locus of control among Minangkabau students. Disertasi, University of Tasmania, Australia.

Nikmarijal, N. (2014). Urgensi Peranan Keluarga bagi Perkembangan Self-esteem Remaja. Jurnal Konseling dan Pendidikan, 2(2), 19-24.

Nirmalasari, L., \& Masusan, K. (2014). Self Esteem, Gender Dan Prestasi Kerja (Study Pada Penyiar Radio Di Kota Bandung): Bandung: STIESTEMBI.

Owens, T. J., Stryker, S., \& Goodman, N. (2006). Extending self-esteem theory and research: Sociological and psychological currents: Cambridge University Press.

Pasaribu, A. C. R. (2011). Hubungan antara Self Esteem dan Adversity Intelligence (Suatu Studi Pada Mahasiswa Universitas Hkbp Nommensen Medan). Jurnal Visi, 19(1), 399-416. 
Rohmah, F. A. (2012). Pengaruh pelatihan harga diri terhadap penyesuaian diri pada remaja. HUMANITAS (Jurnal Psikologi Indonesia), 1(1), 53-63.

Sandha, T., Hartati, S., \& Fauziah, N. (2012). Hubungan antara self esteem dengan penyesuaian diri pada siswa tahun pertama SMA Krista Mitra Semarang. Empati: Jurnal Karya Ilmiah S1 Undip, 47-82.

Sri Mendari, A. (2013). Aplikasi teori hierarki kebutuhan Maslow dalam meningkatkan motivasi belajar mahasiswa. Widya warta, 34(01).

Sujana, Y., \& Wulan, R. (1994). Hubungan antara kecenderungan pusat kendali dengan intensi menyontek. Jurnal Psikologi, 21(1994).

Vohs, K. D., \& Baumeister, R. F. (2016). Handbook of self-regulation: Research, theory, and applications: Guilford Publications.

Yusuf, S., \& Nurihsan, A. J. (2006). Landasan Bimbingan \& Konseling: Program Pascasarjana Universitas Pendidikan Indonesia dengan PT Remaja Rosdakarya.

Zola, N., Ilyas, A., \& Yusri, Y. (2017). Karakteristik Anak Bungsu. Jurnal Konseling dan Pendidikan, 5(3), 109114. 